\title{
sobre: El punto ciego. Antología de la Poesía Visual Argentina de 7000 a.C. al Tercer Milenio / The Blind Spot. Visual Poetry from Argentina, de Jorge Santiago Perednik, Fabio Doctorovich y Carlos Estévez. San Diego: San Diego State
}

University Press, 2016.

y Verónica paula Gómez / Universidad Nacional del Litoral - CONICET

veronicagomez@conicet.gov.ar

Después de veinte años de la gestación del proyecto inicial, se publica El punto ciego, una antología de la poesía visual argentina signada por la difícil tarea de la recopilación y el ordenamiento de un conjunto de obra multifacético y experimental, que ha sostenido su camino al borde de la hegemonía, bajo lo que en el libro se denomina «la teoría del monstruo». Paralelamente a un recorrido lleno de sobresaltos y decepciones en torno a promesas editoriales incumplidas que se suceden durante las últimas dos décadas, las vidas de sus tres hacedores cambian de forma vertiginosa, al ritmo de una generación. Esos escollos parecieran ser, al mismo tiempo, motor de la insistencia en dar a conocer la genealogía que espera silenciosamente el momento para tornarse legible.

Jorge Santiago Pedernik, a quien se dedica la obra entera luego de su muerte en 20II, junto con Fabio Doctorovich y Carlos Estévez bocetaron la idea original y proveyeron la hoja de ruta bajo un objetivo común: la recuperación de un trozo de la historia de la poesía que ha descansado en el punto ciego imperceptible para la mirada hegemónica, en el borde de la letra en la plástica, en el lenguaje reservado a la primacía visual que aisladamente habían sostenido publicaciones periódicas como $X u l$ o el grupo Paralengua. En este sentido, el libro, en principio diverso y con abordajes disímiles entre la inauguración de lo innominado y la explicación de la construcción poética en cada caso, se encauza a partir de la hipótesis de que esa historia merece ser contada, aun cuando para ello hagan falta dos largas décadas de búsqueda de interesados locales y luego internacionales para ser dicha. Es ese deseo poderoso el que moviliza lo que luego de muchas luchas —económicas, políticas, personales - deviene finalmente en la publicación por San Diego State University Press, y recién entonces los vínculos entre las artes plásticas y las letras cobran renovado impulso e interés editorial. Así, esta obra mixta entre texto e imagen, en muchos momentos parece un poema visual en sí mismo y en muchos otros un catálogo deslumbrante que recoge de manera artesanal y ensayística 
mucha información valiosa y devuelve al presente una deuda editorial e histórica con artistas y colectivos dedicados a la poesía visual desde tiempos inmemoriales.

A sabiendas de que esta historia está siendo contada por primera vez, el libro se organiza a partir de tres grandes ejes: la recolección y la forma en que la antología se gestó y se llevó a cabo a lo largo del tiempo, aspectos a los que hicimos alusión en los párrafos anteriores; los «antecedentes» que podrían haber sembrado el desarrollo de la poesía visual, como la Cueva de las Manos en Santa Cruz o el Btoro en Córdoba, ejemplos de una escritura no alfabética, pero en cualquier caso significativa, expresada en superficies visibles para ser comprendida por otros; y el siglo xx casi en toda su extensión, abarcando un desarrollo creciente de obras y de artistas visuales que llegan a los albores de la nueva centuria en convivencia con internet y la literatura electrónica. Se trata de la construcción de una genealogía que tiene la virtud de ordenarse cronológicamente sin perder el tenor de las diferentes hipótesis que subyacen a las obras de una misma época dada, ni de los vínculos diacrónicos que se pueden establecer entre ellas. En este sentido, se postula la idea de que la poesía visual ha sido un lineamiento reprimido, la mancha ciega de nuestra retina que está presente pero no podemos ver, imbuidos dentro de la tradición sustancialista occidental, y este supuesto atraviesa los textos y la recopilación de imágenes expresadas allí.

El aspecto colectivo y múltiple del libro se observa a primera vista en las 328 páginas en papel fotográfico de gran espesor, intercalando ensayo, descripción y obra. Un ojo atravesado por la firma - huella y rudimento del principio de un lenguaje embrionario que no toma la dirección dominante del resto de la poesía consagrada - se posa al inicio y al final del libro, produciendo un oxímoron con la ceguera de su título, como si a aquellos que nos dedicamos a las letras, nos hiciera falta abrir los ojos ante toda esta historia que ha pasado desapercibida al borde del mundo tímido y cohibido de la academia argentina. Prueba de ello es la insistencia de los autores de los textos presentes en la obra en la dificultad de publicar en nuestro país y la decisión final de aceptar la oferta de una editorial universitaria extranjera, con las concesiones políticas que ello conlleva.

El largo recorrido de esta antología de poesía visual podría resumirse sin reducirse, entre el enigma de lo nuevo, que es la materialidad de la letra no verbal, y «el Tarzán del poema», que es monstruoso al tiempo que es sabio en su inteligibilidad. Surcado por la idea del desvío que albergan las imágenes inventadas y no representativas de lo real, las políticas del error se suceden en el tiempo, produciéndose cruces inesperados entre artes plásticas, música, performance y lenguajes no tradicionales — las matemáticas, los códigos informáticos, la señalética-. Esos cruces ameritan, en muchos casos, el desarrollo de instrucciones sobre cómo leer, prótesis que, a su vez, se incorporan a la obra para advertir críticamente las disposiciones dicotómicas entre lo legible y lo ilegible que hemos naturalizado, ciegos.

Dado que se trata de poesía experimental, los compiladores reconocen que la reducción de estas obras a una antología produce una deficiencia de base ya que se trata de poesías sostenidas en muchos casos por artefactos externos que 
requieren de la presencia física de su público en museos, galerías o intervenciones urbanas. En muchos pasajes del libro se encuentra esta especie de nostalgia por la imposibilidad de la experiencia, al tiempo que se celebra lo que aún queda en el terreno de lo ilegible del sentido de lo que se nutren estas imágenes, ubicadas en el punto ciego. Esa inteligibilidad tiene que ver con «el retraso relativo de la poesía en el proceso integrador de las artes», un déficit que este libro busca menguar al abrir camino en las posibilidades visuales de nuestra óptica. 